\title{
Dynamics of the control of Aedes (Stegomyia) aegypti Linnaeus (Diptera, Culicidae) by Bacillus thuringiensis var israelensis, related with temperature, density and concentration of insecticide ${ }^{1}$
}

\author{
Jonny E. Duque L ${ }^{2,3}$ \& Mario Antônio Navarro-Silva ${ }^{3}$
}

${ }^{1}$ Contribution $n^{\circ} 1652$, Departamento de Zoologia.

2CNPq Fellowship. jonnybiomat@ufpr.br; jonnybiomat@hotmail.com

${ }^{3}$ Laboratório de Entomologia Médica e Veterinária, Departamento de Zoologia, Programa de Pós-graduação em Ciências Biológicas, Entomologia. Universidade Federal de Paraná. Caixa Postal 19020, 81531-980 Curitiba-PR, Brasil. mnavarro@ufpr.br.

\begin{abstract}
Dynamics of the control of Aedes (Stegomyia) aegypti Linnaeus (Diptera, Culicidae) by Bacillus thuringiensis var israelensis, related with temperature, density and concentration of insecticide. The dynamics of the control of Aedes (Stegomyia) aegypti Linnaeus, (Diptera, Culicidae) by Bacillus thuringiensis var israelensis has been related with the temperature, density and concentration of the insecticide. A mathematical model for biological control of Aedes aegypti with Bacillus thuringiensis var israelensis (Bti) was constructed by using data from the literature regarding the biology of the vector. The life cycle was described by differential equations. Lethal concentrations (LC50 and LC95) of Bti were determined in the laboratory under different experimental conditions. Temperature, colony, larvae density and bioinsecticide concentration presented marked differences in the analysis of the whole set of variables; although when analyzed individually, only the temperature and concentration showed changes. The simulations indicated an inverse relationship between temperature and mosquito population, nonetheless, faster growth of populations is reached at higher temperatures. As conclusion, the model suggests the use of integrated control strategies for immature and adult mosquitoes in order to achieve a reduction of Aedes aegypti.
\end{abstract}

KEYWORDS. Biological control; environmental variable; Mathematical model.

RESUMO. Dinâmica do controle de Aedes (Stegomyia) aegypti Linnaeus, (Diptera, Culicidae) por Bacillus thuringiensis var israelensis, relacionada com a temperatura, densidade e concentração do inseticida. Foi elaborado um modelo matemático do controle biológico de Aedes aegypti com foco em Bacillus thuringiensis var israelensis (Bti). Na construção do modelo foram utilizados dados da literatura sobre a biologia do vetor, no qual o ciclo de vida foi descrito através de equações diferenciais. As concentrações letais (CL50 e CL95) do Bti foram determinadas no laboratório sob diferentes condições experimentais. As variáveis temperatura, colônia, densidade de larvas e concentração do bioinseticida acusaram diferenças significativas quando analisadas no modelo geral, porém quando analisadas individualmente, apenas a temperatura e concentração apresentaram diferenças. As simulações do modelo indicam que a temperatura afeta inversamente a produção de indivíduos e que os pontos máximos de produção de mosquitos são atingidos mais rápido a temperaturas maiores. Concluímos, com a simulação do modelo, que estratégias integradas de controle de imaturos e adultos devem ser utilizadas para atingir redução expressiva da população de Aedes aegypti.

PALAVRAS-CHAVE. Controle biológico; Modelo matemático; variáveis ambientais.

Dengue and dengue hemorrhagic fevers are diseases which etiologic agents are transmitted by the mosquito vector Aedes aegypti Linnaeus, 1762. This species is also capable of transmitting the yellow fever virus. The vector as well as the disease has become an economic and public health problem. Affected countries invest a significant part of the gross domestic product in the vector-disease control. Despite these efforts, the number of cases in Latin America oscillates year by year and in some cases, epidemics appear (Gubler 2002).

Currently, the main strategies directed at controlling the vector for dengue in Brazil involve chemical organophosphate (OP) and pyrethroid (P) products. In some cases, the population of mosquitoes changes its susceptibility, developing resistance (Macoris et al. 1995; Macoris et al. 2003, Lima et al. 2003, Braga et al. 2004; Duque et al. 2004). The resistance to insecticides can be reduced by rotation with non-chemical products based upon Bacillus thuringiensis var israelensis (Bti), which have demonstrated efficiency for almost thirty years and safety in the environment (Goldber \& Margalit 1977; Kroeger et al. 1995; Almalraj et al. 2000; Batra et al. 2000; Russell et al. 2003).

In the control of mosquitoes with Bti, it is crucial to take into account data for the following variables: temperature, larvae density, origin of populations and concentrations. Previous work has shown that such variables can modify the effectiveness of control efforts on the species of interest (Becker et al.1992, Katbeh-Bader et al. 1999). In specific cases, the mathematical models allow us to analyze all these variables within a specific time interval. This can be done for laboratory or real conditions, predicting the dynamics of populations and helping us to take new directions of control.

Earlier studies based upon mathematical models presented predictions of the action of insecticides on dengue incidence (Newton \& Reiter 1992; Esteva \& Vargas 1998, 1999) including 
environmental factors and the life cycle of the mosquito when dengue is present (Focks et al. 1993a,b; Focks et al. 1995) or the effect of copepods on the control (Duque et al. 2004). Nonetheless, they are designed to study the disease, and in some cases without the inclusion of vector biology. For this reason, the present study aims to understand the dynamics of Ae. aegypti control with Bacillus thuringiensis var israelensis $\mathrm{H}-14$, by the use of a mathematical model simulated with environmental variables and with biological data on the species.

\section{MATERIALAND METHODS}

The methodology of this study is divided in three parts: first, the construction of the mathematical model; second, bioassays with Bti to determinate $\mathrm{LC}_{50}$ and $\mathrm{LC}_{95}$; third, mathematical model simulation with biological data obtained from the literature.

First part: the model was established using differential equations adjusted to the Ae. aegypti biology. Data from the literature allowed determining the rates for birth, increase and survival of each daily biological stage of the species. The control of Bti and treatment alternative is continuous during the period of incidence of the mosquito. Parameters are defined as follows; $\theta$ : daily oviposition rate; $\mu$ : unhatched eggs rate; $\alpha$ : development rate from $\mathrm{O}$ to $\mathrm{L}_{1} ; \sigma_{1}$ : $\mathrm{L}_{1}$ mortality rate; $\pi$ : development rate from $L_{1}$ to $L_{2} ; \sigma_{2}: L_{2}$ mortality rate; $\gamma$ : development rate from $\mathrm{L}_{2}$ to $\mathrm{L}_{3} ; \sigma_{3}: \mathrm{L}_{3}$ mortality rate; $\rho$ : mortality rate of $\mathrm{L}_{3}$ by Bti action; $\psi$ : development rate from $\mathrm{L}_{3}$ to $\mathrm{L}_{4} ; \sigma_{4}$ : mortality rate of $\mathrm{L}_{3} ; \lambda$ : development rate from $\mathrm{L}_{4}$ to $\mathrm{P} ;$ : mortality rate of pupae; $\Omega$ : development rate from Pupae to Adult; $\varepsilon$ : daily mortality rate of adults; C: daily adult emergence rate; B: amplitude modulation of function oscillations; b: frequency of oscillations; t: simulation time (Table I). The starting values for simulations are: $\mathrm{O}=125, \mathrm{~L}_{1}=25, \mathrm{~L}_{2}=24, \mathrm{~L}_{3}=23, \mathrm{~L}_{4}=22, \mathrm{P}$ $=22$ and $\mathrm{A}=29$.

Second part: reared larvae from laboratory were subjected to susceptibility tests with Bti using the liquid product Vectobac-AS (Sumitomo Chemical) 1200 international toxic units (ITU) per milligram. Different Bti concentrations from $0.01 \mathrm{ppm}$ and $0.50 \mathrm{ppm}$ were tested to determine the mortality limits from $1 \%$ and $99 \%$. Five concentrations were ultimately selected for the essays: $0.03 \mathrm{ppm}, 0.06 \mathrm{ppm}, 0.12 \mathrm{ppm}, 0.18$ ppm and $0.25 \mathrm{ppm}$. The bioassays followed procedures established by WHO (1981).

Larvae were assayed for two different density values: 20 or 30 individuals from late third instar and/or earlier fourth at temperatures of 20,25 or $30^{\circ} \mathrm{C}$ and five replicates for each test. The larvae were kept in $300 \mathrm{ml}$ polystyrene vessels (cups) with $150 \mathrm{ml}$ of "Ouro Fino" brand mineral water. In addition to the control assay, five tests were carried out for each larvae density and temperature. During the experiments food was not offered to the larvae, and cups were kept in climatized chambers with $80 \%( \pm 10 \%)$ relative humidity.

For the third part of the methodology, mortality was evaluated 24 hours after the addition of the product. The $\mathrm{LC}_{50}$ and $\mathrm{LC}_{95}$ values were estimated by the Probit GW-Basic analysis (Finney 1981). Statistical calculation of density, temperature and concentration was obtained through variance analysis (ANOVA), where the dependent variable was the mortality by Bti action. The results from the Homogeneity of Variance test (Levene test) were analyzed at significance levels of 5\% ( $\alpha=0.05$ ), the analyses were carried out using the Statistical Package for the Social Sciences (SPSS) v10.0.

\section{RESULTS}

A model is presented with seven differential equations (e1...e.e7) formed by the following variables: O: number of eggs laid by females from variable $A ; L_{1}$ : number of first instar larvae; $\mathrm{L}_{2}$ : number of second instar larvae; $\mathrm{L}_{3}$ : number of third instar larvae; $\mathrm{L}_{4}$ : number of fourth instar larvae; $\mathrm{P}$ : number of pupae; A: number of adults (Figure 1); CA/2 $\theta \mathrm{Sen}^{2}=$ this function determines the fluctuation of adults originated from each female oviposition. It is divided by two according to the sexual male/ female ratio, which tends to be $1: 1$, i.e., from the total of adults, only one half produce eggs.

Differential equations system:

$$
\begin{aligned}
& \frac{d O}{d t}=\frac{C A}{2} \theta+B \operatorname{Sen}^{2}(b t)-\mu O-\alpha O \\
& \frac{d L_{1}}{d t}=\alpha O-\sigma_{1} L_{1}-\pi L_{1} \\
& \frac{d L_{2}}{d t}=\pi L_{1}-\sigma_{2} L_{2}-\gamma L_{2} \\
& \frac{d L_{3}}{d t}=\gamma L_{2}-\sigma_{3} L_{3}-\psi L_{3}-\rho L_{3} \\
& \frac{d L_{4}}{d t} \psi L_{3}-\sigma_{4} L_{4}-\lambda L_{4} \\
& \frac{d p}{d t}=\lambda L_{4}-\tau P-\Omega P \\
& \frac{d A}{d t}=\Omega P-\varepsilon A
\end{aligned}
$$

Bioassays with Bacillus thuringiensis H-14: The temperature, concentration and density interaction of two Ae. aegypti colonies evaluated (Londrina and Rockefeller) indicates the existence of an inversely proportional pattern of concentration versus temperature, i.e. at higher temperatures, a smaller bacillus concentration will be needed to obtain a satisfactory effect (Tables II - V).

The "Levene' test (homogeneity of variances) showed a normal distribution $(\alpha=0.05, p<0.111)$. The analysis of variance (ANOVA) only revealed significant differences when all the variables were analyzed together. The values obtained were: 


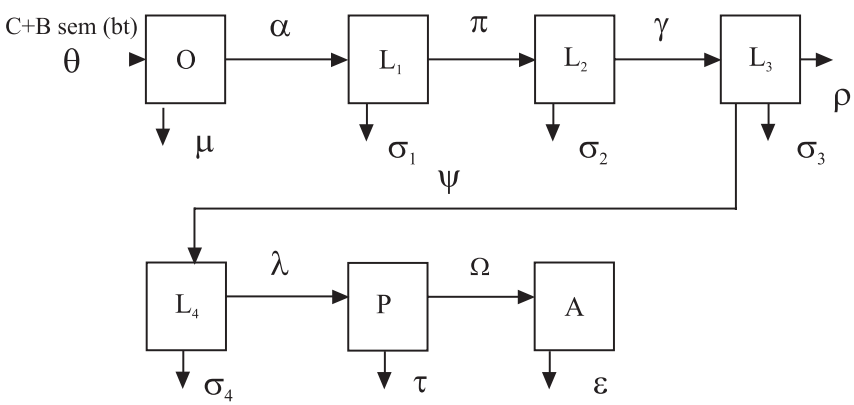

Fig. 1. Flow diagram of the model.

Rockefeller or Londrina colonies $(\alpha=0.05, \mathrm{f}=12.709$, $\mathrm{p}<$ 0.001), Temperatures $(\alpha=0.05, \mathrm{f}=32.552 \mathrm{p}<0.0001)$, Concentration $(\alpha=0.05, \mathrm{f}=39.920, \mathrm{p}<0.0001)$ and Density 20 or $30(\alpha=0.05, \mathrm{f}=4.798, \mathrm{p}<0.034)$ when compared to the Mortality dependent variable.

When the variables were analyzed alone, they did not present relevant differences related to colony $(\alpha=0.05, \mathrm{f}=$ 2.636, $\mathrm{p}<0.110)$ and density $(\alpha=0.05, \mathrm{f}=2.456, \mathrm{p}<0.123)$. This indicates that results are strongly influenced by the temperature. The Tukey HSD (Honestly Significant Difference) test showed differences for the temperature ( $\mathrm{p}<$ 0.05 ) and concentration variables. There are differences for $20^{\circ} \mathrm{C}$ when compared to data for 25 and $30^{\circ} \mathrm{C}$. The concentrations that did not present differences are $0.12 \mathrm{ppm} /$ $0.18 \mathrm{ppm}$ and $0.18 \mathrm{ppm} / 0.25 \mathrm{ppm}$.

Simulations: The simulations carried out present population increase of immature and adult Ae. aegypti in different scenarios depending on the efficiency of the control applied with Bti $(\rho)$, at 20,25 or $30^{\circ} \mathrm{C}$ during a 12 month period. In this dynamics, four hypothetical possibilities were evaluated for the Bti efficiency based on different treatments: a) $\rho=0$, this value indicates the control (without Bti); b) $\rho=0.5$, represents $50 \%$ of larval mortality; c) $\rho=1,100 \%$ of larval mortality; and d) $\rho=1,100 \%$ of larval mortality in addition to a treatment for adults of 0.5 (50\% of mortality) as suggestion for an integrated control (Figures 2, 3 and 4).

The simulation at $20^{\circ} \mathrm{C}$ shows a population increase with stabilization after 8 months (Figure 2). When the efficiency ( $\rho$ ) of $50 \%$ is simulated the population decreases, although this effect is not enough because the objective is to reach a higher number of controlled individuals (Figure 2b). By increasing
Table I. Values of the rates in percentages (\%) used in the simulation of the model for Aedes aegypti.

\begin{tabular}{|c|c|c|c|}
\hline Paramete & $20{ }^{\circ} \mathrm{C}$ & $25^{\circ} \mathrm{C}$ & $30^{\circ} \mathrm{C}$ \\
\hline$\theta$ & $61.1^{\mathrm{e}}$ & $78.9^{\mathrm{e}}$ & $78.9^{\mathrm{e}}$ \\
\hline$\mu$ & $29.61^{\mathrm{f}}$ & $29.61^{\mathrm{f}}$ & $29.61^{\mathrm{f}}$ \\
\hline$\alpha$ & $70.39^{f}$ & $70.39^{f}$ & $70.39^{f}$ \\
\hline$\sigma_{1}$ & $0^{c}$ & $\left(24^{\circ} \mathrm{C}\right) 4^{\mathrm{c}}$ & $0^{c}$ \\
\hline$\sigma_{2}$ & $0^{c}, 3.8^{\mathrm{b}}, 7.5^{\mathrm{a}}$ & $1^{\mathrm{c}}, 3.8^{\mathrm{b}}, 7.5^{\mathrm{a}}$ & $1^{\mathrm{c}}, 3.8^{\mathrm{b}}, 7.5^{\mathrm{a}}$ \\
\hline$\pi$ & $100^{f}$ & $100^{f}$ & $100^{f}$ \\
\hline$\gamma$ & $100^{c}, 96.2^{b}, 95.5^{a}$ & $99^{c}, 96.2^{b}, 95.5^{a}$ & $99^{c}, 96.2^{b}, 95.5^{a}$ \\
\hline$\rho$ & $0,50,100$ & $0,50,100$ & $0,50,100$ \\
\hline$\sigma_{3}$ & $1.9^{\mathrm{c}}, 3.8^{\mathrm{b}}, 2.8^{\mathrm{a}}$ & $2.1^{\mathrm{c}}, 3.8^{\mathrm{b}}, 2.8^{\mathrm{a}}$ & $5^{\mathrm{c}}, 3.8^{\mathrm{b}}, 2.8^{\mathrm{a}}$ \\
\hline$\psi$ & $98.1^{\mathrm{c}}, 96.2^{\mathrm{b}}, 97.2^{\mathrm{a}}$ & $97.9^{\mathrm{c}}, 96.2^{\mathrm{b}}, 97.2^{\mathrm{a}}$ & $95^{\mathrm{c}}, 96.2^{\mathrm{b}}, 97.2^{\mathrm{a}}$ \\
\hline$\sigma_{4}$ & $6^{\mathrm{c}}, 3.3^{\mathrm{b}}, 10^{\mathrm{a}}$ & $3.2^{\mathrm{c}}, 3.3^{\mathrm{b}}, 10^{\mathrm{a}}$ & $6.3^{\mathrm{c}}, 3.3^{\mathrm{b}}, 10^{\mathrm{a}}$ \\
\hline$\lambda^{4}$ & $94^{\mathrm{c},} 96.7^{\mathrm{b}}, 90^{\mathrm{a}}$ & $96.8^{\mathrm{c}}, 96.7^{\mathrm{b}}, 90^{\mathrm{a}}$ & $97.5^{\mathrm{c}}, 96.7^{\mathrm{b}}, 90^{\mathrm{a}}$ \\
\hline $\mathrm{l}$ & $3.19^{c}, 15^{b}, 10^{a}$ & $15.9^{\mathrm{c}}, 15^{\mathrm{b}}, 10^{\mathrm{a}}$ & $1^{\mathrm{c}}, 15^{\mathrm{b}}, 10^{\mathrm{a}}$ \\
\hline$\Omega$ & $91.80^{\mathrm{d}}, 97^{\mathrm{a}}$ & $62.58^{\mathrm{d}}, 97^{\mathrm{a}}$ & $66.34^{\mathrm{d}}, 97^{\mathrm{a}}$ \\
\hline$\varepsilon$ & $4.56^{\mathrm{f}}$ & $4.56^{\mathrm{f}}$ & $4.56^{\mathrm{f}}$ \\
\hline $\mathrm{C}$ & $0.50^{\mathrm{e}}$ & $0.50^{\mathrm{e}}$ & $0.50^{\mathrm{e}}$ \\
\hline B & 8 & 8 & 8 \\
\hline $\mathrm{b}$ & 2 & 2 & 2 \\
\hline $\mathrm{T}$ & 24 & 24 & 24 \\
\hline
\end{tabular}

For some rates, there is only a single value. When there are more because of the different papers, the simulation was always conducted with the lower value.

Hien (1975) ${ }^{\mathrm{a}}$, Bar-Zeev (1957) ${ }^{\mathrm{b}}$, Bar-Zeev (1958) ${ }^{\mathrm{c}}$, Rueda et al (1990) ${ }^{\mathrm{d}}$, Costero et al (1998) $)^{\mathrm{e}}$, Crovello \& Hacker (1972) ${ }^{\mathrm{f}}$.

the efficiency up to $100 \%$ the number of larvae diminishes but the reduction is still insufficient (Figure 2c).

The information generated by the model indicates that effective control strategies focused on larvae and adults must be applied concomitantly with cultural actions. The lack of persistence of this method evaluated with environmental and cultural characteristics leads to continuous appearance of breedings and then a renewal of new adult generations. This factor makes the control actions difficult.

By including control of adults we observe a higher efficiency for reducing the population (Figure 2d). In order to make the mosquito control more effective, according to the model, adult treatment is necessary (Figures 3 and 4 ) in addition to the biological treatment applied to the larvae (L3). We also observe in the simulation that high temperatures influence inversely the production of individuals, therefore, the highest peaks of mosquito population are reached faster at low temperatures. This fact must be applied in the new strategies for mosquito control (Figures 2 to 4 ).

Table II. Lethal concentrations at the $50 \%$ and $95 \%$ levels for Bacillus thuringiensis H-14, confidence interval (CI), $x{ }^{2}$, for the temperatures 20 , 25 or $30^{\circ} \mathrm{C}$, density 20 larvae per replicate of Aedes aegypti colony Rockefeller.

\begin{tabular}{|c|c|c|c|c|c|c|c|}
\hline Temperature & $\mathrm{LC}_{50 \mathrm{ppm}}$ & [ ] & CI & $\mathrm{LC}_{95 \mathrm{ppm}}$ & [ ] & CI & $x^{2}$ \\
\hline $20^{\circ} \mathrm{C}$ & 0.3062 & $3.825^{\circ} \mathrm{C}$ to $20^{\circ} \mathrm{C}$ & $0.0271199-0.374682$ & 0.6364 & $3.625^{\circ} \mathrm{C}$ to $20^{\circ} \mathrm{C}$ & $0.484466-1.042998$ & 2.9288 \\
\hline $25^{\circ} \mathrm{C}$ & 0.0797 & $4.430{ }^{\circ} \mathrm{C}$ to $20^{\circ} \mathrm{C}$ & $0.073252-0.086802$ & 0.1732 & $4.230^{\circ} \mathrm{C}$ to $20^{\circ} \mathrm{C}$ & 0.151675-0.206291 & 0.1147 \\
\hline $30^{\circ} \mathrm{C}$ & 0.0692 & $0.130^{\circ} \mathrm{C}$ to $25^{\circ} \mathrm{C}$ & $0.061251-0.72693$ & 0.1507 & $1.130^{\circ} \mathrm{C}$ to $25^{\circ} \mathrm{C}$ & 0.133177-0.177028 & 3.1183 \\
\hline
\end{tabular}

[ ]:Proportional increase in concentration depending on temperature: lower temperatures / higher temperatures 

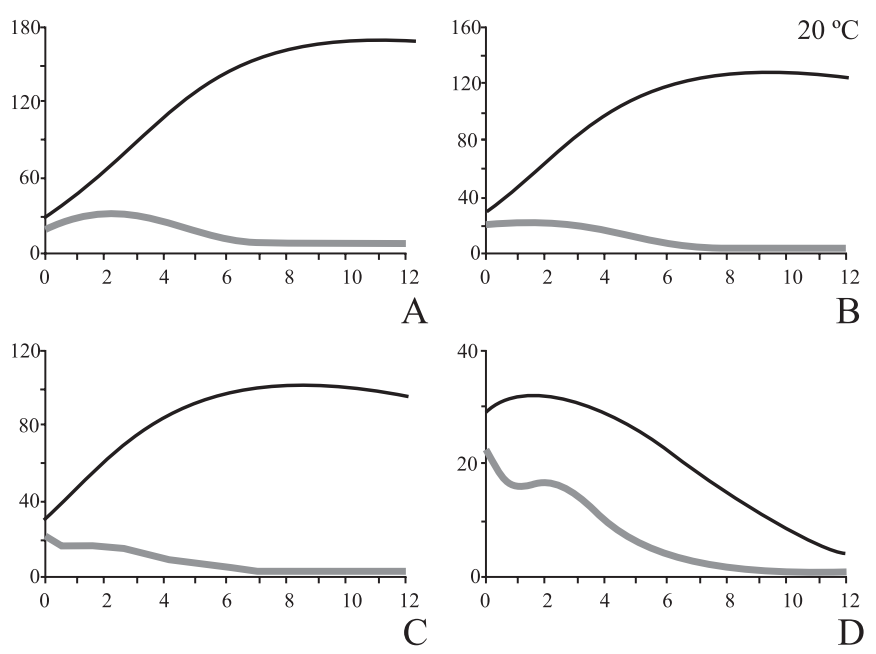

Time in months

Adults $\longrightarrow$ and Larvae

Fig. 2. Scenarios for the control of Aedes aegypti using parameters from table 1 , simulated $20^{\circ} \mathrm{C}$. A = number of adults is represented by the fine line and L3 = number of larvae of third instar is represented by thickest line. Varying the effectiveness of the Bti $(\rho)$, a; $\rho=0, b ; \rho=$ 0.5 , c; $\rho=1$ and $d ; \rho=1$ including alternative treatment with $50 \%$ of adult mortality.

\section{DISCUSSION}

This study meets these expectations quite closely and it reaches our objective by describing the dynamics of the biological control of Ae. aegypti. The focus on the construction of models related to mosquitoes is directed to the analysis of diseases. Only a small number of studies focus on vector control. In expecting to represent the action of every single variable and explore them with differential equations, a different methodology was followed than in earlier works. Our model was directed at the larval stage as consequence of the work of Newton \& Reiter (1992) which reveals that the impact of insecticides at ultra-low volume (ULV) for the adults is minimal and only delays a dengue epidemic.

The inclusion of function Sin allows the equations system to provide useful information for vector control programs. The model can assume periods with a higher production of mosquitoes (rain, temperature and humidity) that could be compared with the index used to evaluate the amount of mosquitoes and their relationship with the disease.

In the experiments related to the determination of lethal concentrations $\left(\mathrm{LC}_{50}\right.$ and $\mathrm{LC}_{95}$ ), it was observed that the Bti
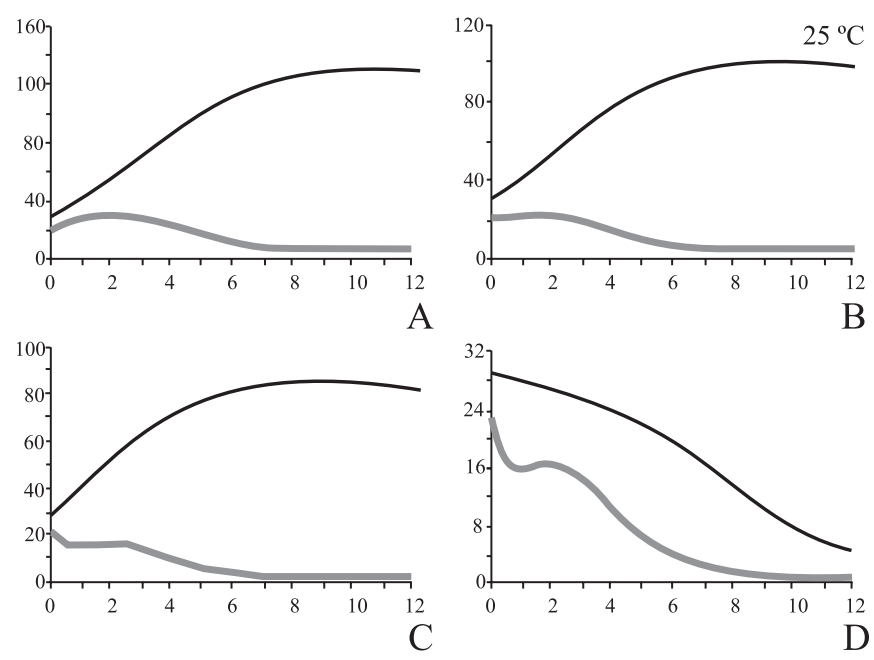

Time in months

Adults $\longrightarrow$ and Larvae

Fig. 3. Scenarios for the control of Aedes aegypti using parameters from table 1 , simulated $25^{\circ} \mathrm{C}$. A = number of adults is represented by the fine line and L3 = number of larvae of third instar is represented by the thickest line. Varying the effectiveness of the Bti $(\rho), a ; \rho=0, b ; \rho=$ 0.5 , c; $\rho=1$ and $d ; \rho=1$ including alternative treatment with $50 \%$ adult mortality.

dose varies depending on the temperature. In relation to the larvae density and colony variables, the concentrations of the product did not influence the lethal concentrations.

In the model we observe that part of the changes taking place in the population density are influenced by the temperature, particularly at values below the thermal limit of the species. For low temperatures, higher concentrations of entomopathogenic bacteria (Bti) are required in order to get the same effect produced at high temperatures.

This fact has also been demonstrated by Becker et al. (1992) with Bacillus thuringiensis $\mathrm{H}-14$ versus Aedes vexans, Aedes aegypti and Culex pipiens, and Katbeh-Bader et al. (1999) by using Bacillus thuringiensis $\mathrm{H}-14$ versus Culiseta longiareolata (Macquart). According to Ramoska \& Pacey (1979), an explanation for this fact is that high temperatures increase the metabolic activity of mosquitoes, and therefore the bacillus ingestion rates. Thus, there is a direct influence on the mortality at high temperatures because of the high concentrations of the pathogen into the digestive system (Ramoska \& Hopkins 1981). This is relevant and attention must be paid because the handbooks used by different

Table III. Lethal concentrations at the 50\% and 95\% level of Bacillus thuringiensis H-14, confidence interval (CI), $x^{2}$, at the temperatures 20 , 25 and $30^{\circ} \mathrm{C}$, density 30 larvae per replicate of Aedes aegypti colony Rockefeller.

\begin{tabular}{|c|c|c|c|c|c|c|c|}
\hline Temperature & $\mathrm{CL}_{50 \mathrm{ppm}}$ & [ ] & & $\mathrm{CL}_{95 \mathrm{ppm}}$ & [ ] & CI & $x^{2}$ \\
\hline $20^{\circ} \mathrm{C}$ & 0.2588 & $2.425^{\circ} \mathrm{C}$ to $20^{\circ} \mathrm{C}$ & $\frac{\mathrm{C1}}{0.237996-0.292949}$ & 05947 & $1.625^{\circ} \mathrm{C}$ to $20^{\circ} \mathrm{C}$ & $\frac{\text { CI }}{0.470474-0.877733}$ & 29288 \\
\hline $25^{\circ} \mathrm{C}$ & 0.1066 & $4.530^{\circ} \mathrm{C}$ to $20^{\circ} \mathrm{C}$ & 0.098446-0.115572 & 0.3684 & $3.330^{\circ} \mathrm{C}$ to $20^{\circ} \mathrm{C}$ & $0.316975-0.442830$ & 0.1147 \\
\hline $30^{\circ} \mathrm{C}$ & 0.0570 & $1.830^{\circ} \mathrm{C}$ to $25^{\circ} \mathrm{C}$ & $0.051962-0.062076$ & 0.1797 & $2.230^{\circ} \mathrm{C}$ to $25^{\circ} \mathrm{C}$ & $0.158516-0.209766$ & 3.1183 \\
\hline
\end{tabular}

[ ]:Proportional increase in concentration depending on temperature: lower temperatures / higher temperatures 
Table IV. Lethal concentrations at the $50 \%$ and 95\% level of Bacillus thuringiensis H-14, confidence interval (CI), $x^{2}$, at the temperatures 20 , 25 and $30^{\circ} \mathrm{C}$, density 20 larvae for replicate of Aedes aegypti colony Londrina.

\begin{tabular}{|c|c|c|c|c|c|c|c|}
\hline Temperature & $\mathrm{LC}_{50 \mathrm{ppm}}$ & [ ] & $\mathrm{CI}$ & $\mathrm{LC}_{95 \mathrm{ppm}}$ & [ ] & CI & $x^{2}$ \\
\hline $20^{\circ} \mathrm{C}$ & 0.0919 & $1.325^{\circ} \mathrm{C}$ to $20^{\circ} \mathrm{C}$ & $0.085028-0.098806$ & 0.1879 & $125^{\circ} \mathrm{C}$ to $20^{\circ} \mathrm{C}$ & $0.168222-0217406$ & 6.368 \\
\hline $25^{\circ} \mathrm{C}$ & 0.0657 & $2.930^{\circ} \mathrm{C}$ to $20^{\circ} \mathrm{C}$ & $0.059670-0.072042$ & 0.1799 & $2.230^{\circ} \mathrm{C}$ to $20^{\circ} \mathrm{C}$ & $0.156613-0.214053$ & 3.0495 \\
\hline $30^{\circ} \mathrm{C}$ & 0.0307 & $2.130^{\circ} \mathrm{C}$ to $25^{\circ} \mathrm{C}$ & 0.0254843-0.034829 & 0.0847 & $2.130^{\circ} \mathrm{C}$ to $25^{\circ} \mathrm{C}$ & $0.071168-0.111868$ & 2.2112 \\
\hline
\end{tabular}

[ ]:Proportional increase in concentration depending on temperature: lower temperatures / higher temperatures
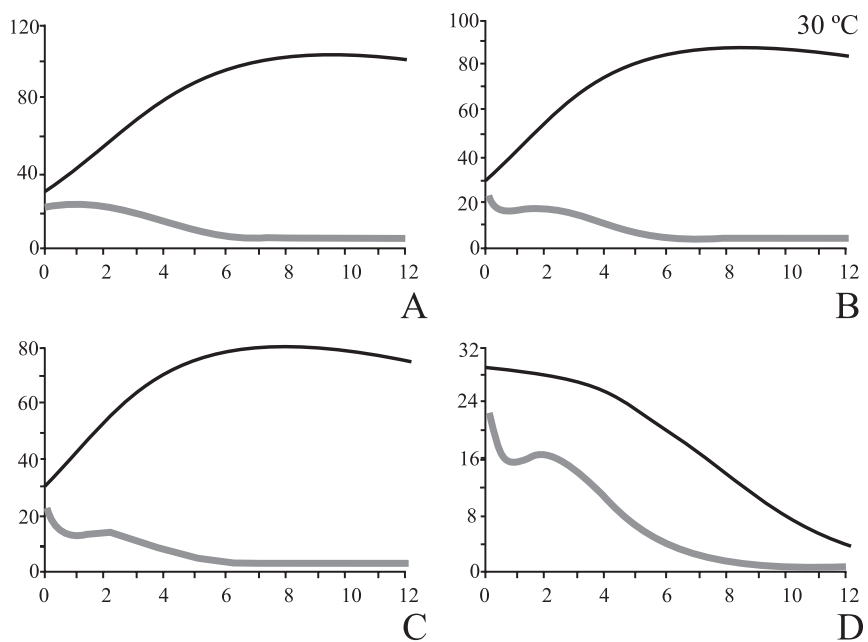

Time in months

Adults $\longrightarrow$ and Larvae

Fig. 4. Scenarios for the control of Aedes aegypti using parameters from table 1 , simulation for $30^{\circ} \mathrm{C} . \mathrm{A}=$ number of adults is represented by the fine line and L3 number of larvae of third instar is represented by the thickest line. Varying the effectiveness of the Bti ( $\rho)$, a; $\rho=0$, b; $\rho=0.5, c ; \rho=1$ and d; $\rho=1$ including alternative treatment with 50 $\%$ adult mortality.

mosquito control sanitary agencies do not strictly consider this parameter.

The density provided little information, perhaps as consequence of the small amplitude of densities used in the experiment. Nevertheless, the density presented a significant difference when it was analyzed within the whole set of variables (temperature, colony and concentration). According to Becker et al. (1992), the density interferes in the efficiency of lethal concentration, indicating that in places with a high larvae density, the control efficiency may reduce with the standard concentrations.
The Rockfeller and Londrina colonies presented different susceptibilities as to lethal concentrations. By comparing both colonies, Londrina is less susceptible to Bti as expected in the first instance, since the reference colony should be more susceptible. Thiéry et al. (1999) have already observed differences between Ae. aegypti populations and the 'boraBora” reference colony which was created over twenty years ago in the laboratory with more susceptibility than the former colony collected in French Guiana. The colonies with more stabilization time in laboratory tend to be more affected by the different products used to date.

The Londrina colony presented more susceptibility, probably because it was subjected to natural conditions of its original place and then it was placed under the stress of the controlled temperature, humidity and photo-phase of the room were the experiments were conducted.

When we compare the results of the present simulation with the experimental data from a similar study such as the model of Newton \& Reiter (1992), it is confirmed that the introduction of isolated agents does not considerably reduce the population of mosquitoes. Our model, formed by different scenarios of control where Bti is applied, indicates the need to add different strategies and methods in order to obtain more efficiency for the control of young forms of Ae aegypti.

As previously mentioned, the model uses experimental data which tend to elevate the laboratory rates compared to the values found in field. Nonetheless, the rates applied to the model simulation can be modified to approach the natural conditions required according to the experience and convenience of researchers when they design the scenarios for the model. We point out the importance of the continuous evaluation that must follow the methods and control strategies.

Acknowledgments. To the Coordenação de Aperfeiçoamento de Pessoal de Nível Superior for the scholarship for master's degree (CAPES). To Drs. Lourdes Esteva de Peralta (UNAM “Departamento de Matemáticas, facultad de Ciencias México”); Anibal Muñoz Loaiza

Table V. Lethal concentrations at the $50 \%$ and $95 \%$ levels of Bacillus thuringiensis H-14, confidence interval (CI), $x^{2}$, at the temperatures 20, 25 and $30^{\circ} \mathrm{C}$, density 30 larvae for feedback from the Aedes aegypti colony Londrina.

\begin{tabular}{|c|c|c|c|c|c|c|c|}
\hline $\begin{array}{c}\text { Aedes aegypti } \\
\text { Londrina }\end{array}$ & $\mathrm{LC}_{50 \mathrm{ppm}}$ & {[]} & IC & $\mathrm{CL}_{95 \mathrm{ppm}}$ & [] & CI & $x^{2}$ \\
\hline $20^{\circ} \mathrm{C}$ & 0.1562 & $1.325^{\circ} \mathrm{C}$ to $20^{\circ} \mathrm{C}$ & $0.147600-0.165341$ & 0.3335 & $125^{\circ} \mathrm{C}$ to $20^{\circ} \mathrm{C}$ & $0.299725-0.382922$ & 0.2090 \\
\hline $25^{\circ} \mathrm{C}$ & 0.0661 & $2.930^{\circ} \mathrm{C}$ to $20^{\circ} \mathrm{C}$ & 0.061198-0.071059 & 0.1707 & $2.230^{\circ} \mathrm{C}$ to $20^{\circ} \mathrm{C}$ & 0.152792-0.195571 & 2.2562 \\
\hline $30{ }^{\circ} \mathrm{C}$ & 0.0600 & $2.130^{\circ} \mathrm{C}$ to $25^{\circ} \mathrm{C}$ & 0.05390-0.066109 & 0.2429 & $2.130^{\circ} \mathrm{C}$ to $25^{\circ} \mathrm{C}$ & $0.208677-0.293724$ & 1.9278 \\
\hline
\end{tabular}

[ ]:Proportional increase in concentration depending on temperature: lower temperatures / higher temperatures 
(UNIQUINDIO Armenia Colombia); H.M. Yang (UNICAMP, Brazil) and Mauricio Osvaldo Moura (UNICENTRO Paraná) for the suggestions for the model. José Lopes and João Zequi (UEL Londrina Paraná) for supplying the Bti and for suggestions. Thanks also the M.Sc Gregorio Guadalupe Carbajal Arízaga (Laboratório de Química do Estado sólido Departamento de Química UFPR) and Dr. Silvio Shigueo Nihei (Museu de Zoologia, Universidade de São Paulo) for the assistance with the english. Also to Drs James Roper and Edílson Batista de Oliveira of UFPR and to M.Sc Leandro Dénis Battirola for the suggestions on statistical analysis.

\section{REFERENCES}

Almalraj, D. D.; S. S. Sahu; P. Jambulingam; D. P. S. Boopathi; M. Kalyanasundaram \& P. K. DAS. 2000. Efficacy of aqueous suspension and granular formulations of Bacillus thuringiensis (Vectobac) against mosquito vectors. Acta Tropica 75: 243-246.

Bar-Zeev, M. 1957. The effect of density on the larvae of a mosquito and its influence on fecundity. Bulletin of the Research Council of Israel 6B. 220-228.

Bar-Zeev, M. 1958. The effect of temperature on the growth rate and survival of the immature stages of Aedes aegypti (L). Bulletin Entomological Research 49: 157-163.

Batra, C. P.; P. K. Mittal \& T. Adakt. 2000. Control of Aedes aegypti breeding in desert coolers and tires by use of Bacillus thuringiensis var israelensis formulation. Journal of the Americam Mosquito Control Association 16: 321-323.

Becker, N.; M. Zgomba; M. Ludwing; D. Petric \& F. Rettich. 1992. Factors influencing the activity of Bacillus thuringiensis var isaelensis treatments. Journal of the Americam Mosquito Control Association 8: 285-289.

Braga, I. A.; J. B. P. Lima; S. S. Soares \& D. Valle. 2004. Aedes aegypti resistance to temephos during 2001 in several municipalities in the States of of Rio de Janeiro, Sergipe, and Alagoas, Brazil. Memórias do Instituto Oswaldo Cruz 99: 199-203.

Costero, A.; J. D. Edman; G. G. Clark \& T. W. Scott. 1998. Life table study of Aedes aegypti (Diptera:Culicidae) in Puerto Rico fed only human blood versus blood plus sugar. Journal of Medical Entomology 35: 809-813.

Crovello, T. J. \& C. S. Hacker. 1972. Evolutionary strategies in Life Table Characteristics among feral and urban strains of Aedes aegypti (L) Evolution 26: 185-196.

Duque, J. E. L.; M. M. Ferrer; F. A. Dos Anjos; E. F. Kuwabara \& M. A. Navarro-Silva. 2004. Susceptibilidade de Aedes aegypti aos inseticidas temephos e cipermetrina, Brasil. Revista de Saúde Pública 38: 842-843.

Duque J. E. L.; A. L. Muñoz \& M. A. Navarro-Silva. 2004. Modelo de simulación para el control del mosquito Aedes aegypti, transmisor del dengue y la fiebre amarilla, por el crustáceo Mesocyclops spp. Revista de Salud Pública 6: 87-89.

Esteva. L \& C. Vargas. 1998. Analysis of dengue disease transmission model. Mathematical Biosciences 150: 131-51.

Esteva. L \& C. Vargas. 1999. A model for dengue disease with variable human population. Journal of Mathematical Biology 38: 22040 .

Finney, D. J. 1981. Probit Analysis, S. Chand \& Company Ltd, Ram Nagar, New Delhi, 333 pp.

Focks, D. A.; D. G. Haile; E. Daniels \& C. A. Mount. 1993a. Dynamic life table model for Aedes aegypti (Diptera:Culicidae): analysis of the literature and model development. Journal of Medical Entomology 30: 1003-17.

Focks, D. A.; D. G. Haile; E. Daniels \& C. A. Mount. 1993b. Dynamic life table model for Aedes aegypti (Diptera:Culicidae): simulation results and validation. Journal of Medical Entomology 30: 101828

Focks, D. A.; E. Daniels; D. G. Haile \& J. E. Keesling. 1995. A simulation model of the epidemiology of urban dengue fever: literature anaysis, model development, preliminary validation, and samples of simulation results. The American Journal of Tropical Medicine and Hygiene 53: 489-506.

Goldberg, L. J \& J. Margalit. 1977. A bacterial spore demostrating rapid larvicidal activity against Anopheles serguetii, Uranotaenia unguiculata, Culex univitattus, Aedes aegypti and Culex pipiens. Mosquito News 37: 355-358.

Gubler, D. J. 2002. Epidemic dengue/dengue hemorrhagic fever as a public health, social and economic problem in the 21st century. Trends in Microbiology 10: 100-103.

Hien, Do S. I. 1975. Biology of Aedes aegypti (L, 1762) and Aedes albopictus (Skuse, 1895) (Diptera:Culicidae). III. Effect of certain enviromental conditions on the development of larvae and pupae. Acta Parasitologica Polonica 23: 553-568.

Katbeh-Bader, A.; H. Khyami-Horani \& H. Mohsen. 1999. Effect of temperature on the susceptibility of Culiceta longiareolata (Macquart) (Dip.,Culicidae) to two standard strains of biocontrol bacteria. Journal of Applied Entomology 123: 629-631.

Kroeger, A.; U. Dehlinger; G. Burkhardt; W. Atehortua; H. Anaya \& N. Becker. 1995. Community based dengue control in Columbia: people's knoweledge and practice and the potential contribution of the biological larvicide Bti (Bacillus thuringiensis israelensis). Tropical Medicine and Parasitology 46: 241-246.

Lima, J. B. P.; M. P. Cunha; R. Carneiro da Silva; A. K. Galardo; S. S. Soares; I. A. Braga; R. P. Ramos \& D. Valle. 2003. Resistance of Aedes aegypti to organophosphates in several municipalities in the state of Rio de Janeiro and Espíritu Santo, Brazil. The Americam Journal of Tropical Medicine and Hygiene 68: 329-333.

Macoris, M. L. G.; M. F. Camargo; I. G. Silva; L. Takaku \& M. T. Andrighetti. 1995. Modificação da Susceptibilidade de Aedes (Stegomyia) aegypti ao Temephos. Revista de Patologia Tropical 24: $31-40$.

Macoris, M. L. G.; M. T. Andrighetti; L. Takaku; C. M. Glasser; V. C. Garbeloto \& J. E. Bracco. 2003. Resistance of Aedes aegypti from the state of São Paulo, Brazil, to Organophosphates insecticides. Memórias do Instituto Oswaldo Cruz 98: 703-708.

Newton, E. A. C. \& P. Reiter. 1992. A model of the transmission of dengue fever with an evaluation of the impact of ultra-low volume (ULV) insecticide applications on dengue epidemics. The Americam Journal of Tropical Medicine and Hygiene 47: 709-720.

Ramoska, W. A. \& T. L. Hopkins. 1981. Effects of mosquito larval feeding behavior on Bacillus sphaericus efficacy. Journal of Invertebrate Pathology 37: 269-272.

Ramoska, W. A. \& C. Pacey. 1979. Food availability and period of exposure as factors of Bacillus sphaericus efficacy on mosquito larvae. Journal of Economy Entomology 72: 523-525.

Rueda, L. M.; R. Patel; R. C. Axtell \& Stinner. 1990. TemperatureDependent Developmente and Survival Rates of Culex quinquefascitus and Aedes aegypti (Diptera: Culicidae). Journal Medical of Entomology 27: 892-898.

Russell, T. L.; M. D. Brown; D. M. Purdie; P. A. Ryan \& B. H. Kay. 2003. Efficacy of VectoBac (Bacillus thuringiensis variety israelensis) Formulations for Mosquito Control in Australia. Ecotoxicology 96: 1786-1791.

Thiéry, I.; F. Fouque; B. Gaven \& C. Lagneau. 1999. Residual activity of Bacillus thuringiensis servars medellin and jegathesan on Culex pipiens and Aedes aegypti larvae. Journal of the Americam Mosquito Control Association 15: 371-379.

World Health Organization. 1981. Report of infromal consultation on standardization of Bacillus thuringiensis $\mathbf{H}-14$. Mimeographed documents TDR/BVC/BTH-14,WHO/VCB/81-828, Geneva.

Received 09/11/2005; accepted 24/10/2006 